\title{
Long-Term Durability of PBI-Based HT-PEM Fuel Cells: Effect of Operating Parameters
}

Søndergaard, Tonny; Cleemann, Lars Nilausen; Becker, Hans; Steenberg, Thomas; Hjuler, Hans Aage; Seerup, Larisa; Li, Qingfeng; Jensen, Jens Oluf

Published in:

Journal of the Electrochemical Society

Link to article, DOI:

10.1149/2.0081806jes

Publication date:

2018

Document Version

Publisher's PDF, also known as Version of record

Link back to DTU Orbit

Citation $(A P A)$ :

Søndergaard, T., Cleemann, L. N., Becker, H., Steenberg, T., Hjuler, H. A., Seerup, L., Li, Q., \& Jensen, J. O. (2018). Long-Term Durability of PBI-Based HT-PEM Fuel Cells: Effect of Operating Parameters. Journal of the Electrochemical Society, 165(6), F3053-F3062. https://doi.org/10.1149/2.0081806jes

\section{General rights}

Copyright and moral rights for the publications made accessible in the public portal are retained by the authors and/or other copyright owners and it is a condition of accessing publications that users recognise and abide by the legal requirements associated with these rights.

- Users may download and print one copy of any publication from the public portal for the purpose of private study or research.

- You may not further distribute the material or use it for any profit-making activity or commercial gain

- You may freely distribute the URL identifying the publication in the public portal 


\title{
Long-Term Durability of PBI-Based HT-PEM Fuel Cells: Effect of Operating Parameters
}

\author{
Tonny Søndergaard, ${ }^{1}$ Lars Nilausen Cleemann, ${ }^{1, *, z}$ Hans Becker, ${ }^{1}$ Thomas Steenberg, ${ }^{2}$ \\ Hans Aage Hjuler, $\circledast^{2, *}$ Larisa Seerup, ${ }^{1}$ Qingfeng $\mathrm{Li},{ }^{1, *}$ and Jens Oluf Jensen ${ }^{1}{ }^{1, *}$
}

${ }^{1}$ Department of Energy Conversion and Storage, Technical University of Denmark, 2800 Lyngby, Denmark

${ }^{2}$ Danish Power Systems Ltd., 3490 Kvistgård, Denmark

This work studies the long-term durability of high-temperature polymer electrolyte membrane fuel cells based on acid-doped polybenzimidazole membranes. The primary focus is on acid loss via the evaporation mechanism, which is a major cause of degradation in applications that involve long-term operation. Durability is assessed for 16 identically fabricated membrane electrode assemblies (MEAs), and evaluations are carried out using operating parameters as stressors with gas stoichiometries ranging from 2 to 25 , current densities from 200 to $800 \mathrm{~mA} \mathrm{~cm}^{-2}$, and temperatures of 160 or $180^{\circ} \mathrm{C}$. Cell diagnostics are composed of time resolved polarization curves, post mortem analysis, and in situ temperature measurements. A major part of the cell degradation during these steady-state tests can be ascribed to increasing area-specific series resistance. By means of post mortem acid-loss measurements, the degradation is correlated to the temperature and to the accumulated gas-flow volume. Such relations are indicative of acid loss via evaporation. Current density also plays a critical role for the acid loss and, thus, for the overall cell degradation. The effect of current is likely tied to mechanisms that involve water generation, migration of electrolyte ions, and locally elevated temperature inside the MEAs.

(C) The Author(s) 2018. Published by ECS. This is an open access article distributed under the terms of the Creative Commons Attribution Non-Commercial No Derivatives 4.0 License (CC BY-NC-ND, http://creativecommons.org/licenses/by-nc-nd/4.0/), which permits non-commercial reuse, distribution, and reproduction in any medium, provided the original work is not changed in any way and is properly cited. For permission for commercial reuse, please email: oa@electrochem.org. [DOI: 10.1149/2.0081806jes]

(cc) BY-NC-ND

Manuscript submitted November 27, 2017; revised manuscript received February 9, 2018. Published February 22, 2018. This paper is part of the JES Focus Issue on Proton Exchange Membrane Fuel Cell (PEMFC) Durability.

Since the polybenzimidazole (PBI) polymer acts as a Brønsted base in relation to phosphoric acid, membranes of PBI can be doped with phosphoric acid through acid-base complexation. Some of the $\mathrm{H}_{3} \mathrm{PO}_{4}$ molecules, 2 per polymer repeat unit, are then bound to the basic functional sites of the polymer. However, excess acid is essential in order to attain a conductivity that is high enough for use as electrolyte in a polymer electrolyte membrane fuel cell (PEMFC). Fuel cells based on this type of electrolyte are known as high-temperature (HT-)PEMFCs, typically operating at temperatures of $140-180^{\circ} \mathrm{C}$. Phosphoric acid-doped PBI membranes can be prepared either by direct (or so-called sol-gel) casting from a solution of PBI dissolved in polyphosphoric acid (PPA) or by solution casting of a PBI film via solvent evaporation, for which acid-doping follows subsequently. ${ }^{1}$

For HT-PEMFCs, the cell performance usually increases to a stable state within the first few hundred hours of operation. This activation of the cell might be a consequence of acid redistribution in the membrane electrode assembly (MEA). ${ }^{2-4}$ Such redistribution of acid also implies susceptibility to its loss, however, because it is a testament to the mobility of the doping-acid. ${ }^{5-7}$ As reviewed by Jakobsen et al., 8 a number of mechanisms have been proposed to explain the loss of doping-acid from PBI membranes, including evaporation into the gas phase and a so-called steam distillation mechanism, the latter of which has been proposed governed by temperature as well as humidity. ${ }^{9} \mathrm{Mi}-$ gration of electrolyte ions might also be an issue with respect to acid loss, particularly if the proton transference number deviates significantly from the maximum value for phosphoric acid (ca. 0.97). $5,7,10-13$ For phosphoric acid, such deviation becomes more pronounced the farther away the water content is deviating from the composition that corresponds to $\mathrm{H}_{3} \mathrm{PO}_{4}{ }^{12}$ As such, migration of electrolyte ions may be encouraged both by condensation and by uptake of water, partly because of consequential formation of charged phosphates or hydronium ions. As a result, the ionic conductivity in phosphoric acid, which is usually ascribed to structural diffusion of protons via the Grotthuss mechanism, might in part be attributed to migration transfer of ions

\footnotetext{
*Electrochemical Society Member.
}

zE-mail: lncl@dtu.dk other than protons via the vehicle mechanism. ${ }^{12,14}$ Any dehydration of the doping-acid-though not a loss per se-will manifest itself in reduced ion conductivity of the electrolyte just like the mechanisms that are causing actual loss of acid. ${ }^{15}$

Evaporation of acid is assumed to be one of the most critical acidloss mechanisms and is exacerbated by increasing temperature as determined by Brown and Whitt, ${ }^{16}$ albeit for temperatures that are higher $\left(\geq 220^{\circ} \mathrm{C}\right)$ than the operating point of HT-PEMFCs. Their results agree with later investigations of the acid vapor pressure over boiling phosphoric acid. ${ }^{17}$ As reviewed by Jakobsen et al., ${ }^{8}$ a presentiment for acid loss via the evaporation mechanism is evident throughout literature in that a large amount of the acid-loss measurement records are based on off-gas analysis. ${ }^{9,18-30}$ Many of the measurements have shown very low loss rates, however, suggesting that this mode of degradation is a minor issue in relation to the 2020 lifetime targets set out by the US Department of Energy, i.e., $<10 \%$ degradation over $80000 \mathrm{~h}$ for steady-state applications involving cogeneration of heat and power. ${ }^{31}$ On the other hand, by taking acid re-condensation in the exhaust tubes into consideration, Eberhardt et al. ${ }^{23}$ estimated significant rates of acid evaporation from MEAs that were based on PPA membranes when subjected to an accelerated stress test that utilized gas-flow rate and temperature as stressors. They showed significant acid evaporation even at mild steady-state operation conditions and concluded that the acid evaporation per unit time was independent of current density, though proportionally increasing with the supplied absolute flow rate and exponentially exacerbated by elevation of the temperature.

By investigating the performance and lifetime of single cells, the work that is presented here elaborates on the present understanding of HT-PEMFC durability. The tested cells are from the same manufacturing batch of MEAs and are based on membranes that have been prepared by solution casting via solvent evaporation. Using operating parameters as stressors, the durability is investigated as a function of gas-flow rate, temperature, and current density. Time resolved polarization characteristics, post mortem analysis, and in situ temperature measurements have been carried out to elucidate the degradation mechanisms. Extreme cases for each of the investigated stressors are warranted by the disparate conditions that HT-PEMFCs experience when used in various applications or with the employ of different 
Table I. Gas stoichiometries and relative humidity of the cathode exhaust for samples operated at individual combinations of gas-flow rates, current densities, and temperatures. Relative humidities are calculated by simplified assumption of neglegible amount of water in the inlet air and that all product water remains on the cathode side.

\begin{tabular}{|c|c|c|c|c|c|c|c|c|}
\hline & \multicolumn{2}{|c|}{ Flow rate / $\mathrm{NmL} \mathrm{min}^{-1}$} & \multicolumn{2}{|c|}{$200 \mathrm{~mA} \mathrm{~cm}^{-2}$} & \multicolumn{2}{|c|}{$600 \mathrm{~mA} \mathrm{~cm}^{-2}$} & \multicolumn{2}{|c|}{$800 \mathrm{~mA} \mathrm{~cm}^{-2}$} \\
\hline & $\mathrm{H}_{2}$ & Air & $\lambda_{\mathrm{H} 2} / \lambda_{\text {Air }}$ & $\mathrm{RH} / \%$ & $\lambda_{\mathrm{H} 2} / \lambda_{\text {Air }}$ & $\mathrm{RH} / \%$ & $\lambda_{\mathrm{H} 2} / \lambda_{\text {Air }}$ & $\mathrm{RH} / \%$ \\
\hline \multirow[t]{3}{*}{$160^{\circ} \mathrm{C}$} & $70 \pm 6 \%$ & $168 \pm 14 \%$ & $5.4 / 6.6$ & 1.1 & $2.0 / 1.6$ & 4.8 & - & - \\
\hline & $143 \pm 12 \%$ & $421 \pm 7 \%$ & $11.8 / 14.5$ & 0.5 & $3.4 / 5.1$ & 1.4 & $3.2 / 3.4$ & 2.2 \\
\hline & $289 \pm 4 \%$ & $724 \pm 3 \%$ & $22.6 / 25.2$ & 0.3 & $8.2 / 8.4$ & 0.8 & $5.7 / 6.0$ & 1.2 \\
\hline \multirow[t]{3}{*}{$180^{\circ} \mathrm{C}$} & $70 \pm 6 \%$ & $168 \pm 14 \%$ & $5.9 / 6.1$ & 0.7 & $2.0 / 2.0$ & 2.4 & - & - \\
\hline & $143 \pm 12 \%$ & $421 \pm 7 \%$ & $12.0 / 14.5$ & 0.3 & $4.3 / 5.0$ & 0.9 & $2.9 / 3.6$ & 1.2 \\
\hline & $289 \pm 4 \%$ & $724 \pm 3 \%$ & $23.1 / 25.1$ & 0.2 & $7.9 / 8.5$ & 0.5 & $5.7 / 6.3$ & 0.7 \\
\hline
\end{tabular}

operation strategies, e.g., high temperature for improved performance, high current density during transient operation, and high gas-flow rate for stack cooling with air. Thus, rather than being a study of attainable lifetime or a materials screening process, the results that are presented here provide insights into mechanistic degradation, suitability of operating parameters for use as stressors in accelerated stress tests, and applicability of the HT-PEMFC system in relation to particular operation modes and strategies.

\section{Experimental}

Preparation of MEAs.-Membranes of $m$-PBI with a thickness of $40 \mu \mathrm{m}$ were fabricated by solution casting from a polymer solution in $\mathrm{N}, \mathrm{N}$-dimethylacetamide. After complete evaporation of the solvent, the membranes were submerged in phosphoric acid $\left(85 \mathrm{wt} \% \mathrm{H}_{3} \mathrm{PO}_{4}\right)$ at room temperature for at least $48 \mathrm{~h}$. Immediately after acid-doping and removal of excess acid from the membrane surface, an acid-doping level (ADL) of approximately $9.3-9.6 \mathrm{H}_{3} \mathrm{PO}_{4}$ molecules per polymer repeat unit was determined gravimetrically.

The gas diffusion electrodes were composed of a non-woven carbon cloth gas diffusion layer (GDL) coated with a microporous layer (MPL) (Freudenberg FCCT H23C2). A catalytic layer was sprayed onto the MPL using a Sonotek ultrasonic spray robot. The catalyst ink was composed of Pt/C (ca. 58.5 wt\%, Johnson Matthey HiSPEC 9100) and of formic acid as dispersant. The gravimetrically determined platinum loadings for the anodes and cathodes were approximately 0.35 and $0.83 \mathrm{mg} \mathrm{cm}^{-2}$, respectively.

Each MEA was prepared by sandwiching a membrane between two electrodes $\left(3.1 \times 3.1 \mathrm{~cm}^{2}\right)$ followed by hot pressing at $200^{\circ} \mathrm{C}$ and 4.1 MPa for $3 \mathrm{~min}$. Before hot pressing, frames of polysulfone were introduced in the MEA to reinforce the membrane along the periphery of the electrodes, i.e., the nonreactive gas sealing area. The active area of each resulting MEA was $8.8 \mathrm{~cm}^{2}$. As elaborated in the first section of the Results and discussion, all MEAs were from the same manufacturing batch, for which the fabrication dates back to 2012 .

Cell assembly and control.-The MEAs were tested as single cells. Gases were supplied via graphite composite flow plates for HT-PEMFCs with parallel gas channels that were $1 \mathrm{~mm}$ wide and $1 \mathrm{~mm}$ deep, separated from one another by a spacing of $1 \mathrm{~mm}$. The flow fields of the anode and cathode were arranged perpendicular relative to one another (cross-flow orientation) and were supplied with hydrogen and air, respectively. Gaskets of polytetrafluoroethylene with a thickness of $150 \mu \mathrm{m}$ were used for gas sealing between the MEA and the flow plates. A sheet of expanded flexible graphite (Papyex, Carbone Lorraine) with an uncompressed thickness of $1 \mathrm{~mm}$, was used for gas sealing between the flow plates and the silver- or gold coated current collectors. On the backside of the current collectors, a $1 \mathrm{~mm}$ thick layer of a fluoroelastomer (Viton) was used for gas sealing and for electrical insulation from the cell housing end plates. Two aluminum end plates equipped with heating elements were used to clamp the MEA, flow plates, current collectors, and all of the seals. Clamping was done using one pair of $8 \mathrm{~mm}$ nuts and bolts in each of the four end plate corners and tightening these to a torque of 1 $\mathrm{Nm}$. Prior to clamping, two sets of spring discs were introduced onto each bolt, one set on either side of the cell. Finally, the fuel cells were mounted onto individual test stations of an in-house build test rack.

Gas-flow rates were controlled using 1355 Sho-Rate variable-area flow meters with maximum nominal flow ranges of $318 \mathrm{NmL} \mathrm{min}^{-1}$ for hydrogen and either 483 or $767 \mathrm{NmL} \mathrm{min}^{-1}$ for air, depending on the material of the floater inside the flow meter. The output of such flow meters can vary to some extent, though their setpoints had been calibrated in the range from their maximum and down to $50 \mathrm{~mL}$ $\min ^{-1}$ using a Bios definer 220, which has a measurement accuracy of $\pm 1 \%$. Flow-rate setpoints were maintained within the calibrated range at all times. The setpoint temperature for each cell was maintained in the end plate using CAL 3300 PID temperature controllers. Labview was used for all electrochemical control and for monitoring of the fuel cells.

Samples and test procedures.-Start-up of cells was done by heating to $120^{\circ} \mathrm{C}$ followed by the addition of $\mathrm{H}_{2}$ /air in constant flow rates of ca. $50 / 117 \mathrm{NmL} \mathrm{min}^{-1}$. A current density of $200 \mathrm{~mA} \mathrm{~cm}{ }^{-2}$ was then maintained until the desired temperature of either 160 or $180^{\circ} \mathrm{C}$ had been reached. After 30 min of stabilization at these conditions, a beginning-of-life $(\mathrm{BoL})$ polarization curve was recorded followed by steady-state operation.

Polarization curves were recorded by means of current step potentiometry in the range from 0 to $1000 \mathrm{~mA} \mathrm{~cm}^{-2}$. A polarization curve was recorded at BoL and then approximately once every week $(\approx 170 \mathrm{~h})$. All polarization curves were initiated with $10 \mathrm{~min}$ at open circuit voltage $(\mathrm{OCV})$ prior to recording of its first data point. For the remainder of the polarization curve, a stabilization time of $2 \mathrm{~min}$ at each current step was enforced prior to recording of a data point. The direct current characteristics were recorded at OCV, 2.5, 5, 12.5, 25, $32.5,50,80,125,200,400,600,800$, and $1000 \mathrm{~mA} \mathrm{~cm}^{-2}$. However, if the cell potential ever reached $0 \mathrm{~V}$ during the scan, the sequence was terminated and steady-state operation was recommenced. Polarization curves were recorded with one set of constant flow rates for the current densities up to $200 \mathrm{~mA} \mathrm{~cm}{ }^{-2}$ and with another set of constant flow rates for the higher current densities between $200-1000 \mathrm{~mA} \mathrm{~cm}^{-2}$. At 200 and $1000 \mathrm{~mA} \mathrm{~cm}^{-2}$, the applied flow rates corresponded to $\mathrm{H}_{2}$ /air stoichiometries of $2 / 4$. Precedence was, at all times, given to maintaining the flow rates within the calibrated range of the flow meters. After measuring a polarization curve, operating parameters were set to those specified for steady-state operation.

Steady-state operating parameters were varied between each of the 16 MEAs; cf. Table I. Each cell was operated with one of three different current densities $\left(200,600\right.$, or $\left.800 \mathrm{~mA} \mathrm{~cm}^{-2}\right)$, one of two different temperatures $\left(160\right.$ or $\left.180^{\circ} \mathrm{C}\right)$, and with one of three different sets of hydrogen and air flow rates (constant $\mathrm{H}_{2}$ /air midrange flow

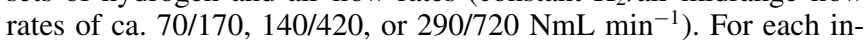
dividual sample, any departures in the flow-rate setpoints from these midranges are encompassed by the flow-rate envelopes in Table I, given as percent of the midrange flow. Any discrepancies between samples in their listed stoichiometries or calculated relative humidity can be explained by these variations within the flow-rate envelopes. 
The exact flow-rate setpoints for each individual sample can be found in the Supplementary Information. It is worth noting that in-line diagnostics, such as time resolved polarization curves, have been masked from all presented steady-state data for visual clarification. This is the main reason for occasional discontinuities in the steady-state curves. It should also be noted, that of the samples shown in Table I, it is not every single lifetime curve that is presented in the Results and Discussion. This is a deliberate choice made to promote clarity. However, the lifetime data for all of the tested samples can be found in the Supplementary Information.

Post mortem titration.-The area-specific acid content of the MEAs has been determined by acid-base titration using a die-cut circular piece of MEA $(\varnothing=1.26 \mathrm{~cm}$, ca. $14.2 \%$ of the active area). Each piece was leached of acid in $150 \mathrm{~mL}$ ultrapure water (Sartorius Arium pro UV, ASTM Type 1 quality), which was stirred overnight. The solution was titrated with standardized $0.05 \mathrm{M} \mathrm{NaOH}$ (SigmaAldrich) using a Metrohm 808 Titrando titrator. In order to accelerate leaching of residual acid, addition of titrant was paused when the $\mathrm{pH}$ of the solution approached the first equivalent point for phosphoric acid. After waiting for at least $60 \mathrm{~min}$, the titration was brought to conclusion, ending with a $\mathrm{pH}$ of 4.9. The loss of acid was evaluated as a relative comparison to the acid content at BoL, which had been determined for reference MEAs from the same batch. Previous use of this method has shown good repeatability in that the standard deviations between acid measurements on individual cutout samples from the same BoL MEA were less than $1.3 \%$ of the average. ${ }^{32}$ Furthermore, it has been shown that more than $90-95 \%$ of the initial BoL acid content can be garnered. Some departure from $100 \%$ extraction is expected, particularly considering the much stronger interaction that exists between the PBI polymer and the final portion of acid. In light of this and of the good repeatability, any acid determinations that are made using this method are believed to accurately reflect the actual content of free acid in the MEAs.

In situ temperature measurements.-A type $\mathrm{R}$ micro-wire thermocouple was manufactured and subsequently embedded into the electrolyte of an MEA by sandwiching it in between two acid-doped membranes, each with a dry-state thickness of $20 \mu \mathrm{m}$. The thermocouple and membranes were integrated as part of an MEA by hot pressing as described in the Preparation of MEAs section. The measurement junction of the thermocouple was located approximately in the center of the MEA. This sample was made in addition to the 16 other MEAs. The thermocouple wires were from Omega Corporation and were of noble metals ( $\mathrm{Pt}$ and $\mathrm{Pt} / 13 \mathrm{Rh}$ ) capable of enduring in situ test conditions. The wires had a diameter of approximately $25 \mu \mathrm{m}$ and were welded together using a micro-burner. They were then attached to $\mathrm{Cu}$-based compensation extension wires, which have similar thermoelectrical properties up to $200^{\circ} \mathrm{C}^{33}$ The extension wires were connected to an RS-1316 dual data logger thermometer for temperature display, data collection, and automatic compensation for the ambient reference junction temperature. After fabrication but prior to embedding into the MEA, the thermocouple had been subjected to a stabilization treatment at $500^{\circ} \mathrm{C}$ in air for $42 \mathrm{~h}$ followed by ex situ calibration against an Ametek Jofra CTC 650A temperature calibrator equipped with a Pt 100 resistance thermometer. Other experimental details for the fabrication of the micro-wire thermocouple can be found in the Supplementary Information.

\section{Results and Discussion}

Remarks on MEA batches and BoL polarization curves.-By using MEAs from a single manufacturing batch, this study is expected to have minimized most of the cell inconsistencies that might otherwise have arisen due to continuous improvement of materials and manufacturing procedures. If unaccounted for, such discrepancies might have devolved over the course of long-term operation to influence the parametric investigation at hand with an unrelated effect. However, the drawback of this approach is that continuous development of the

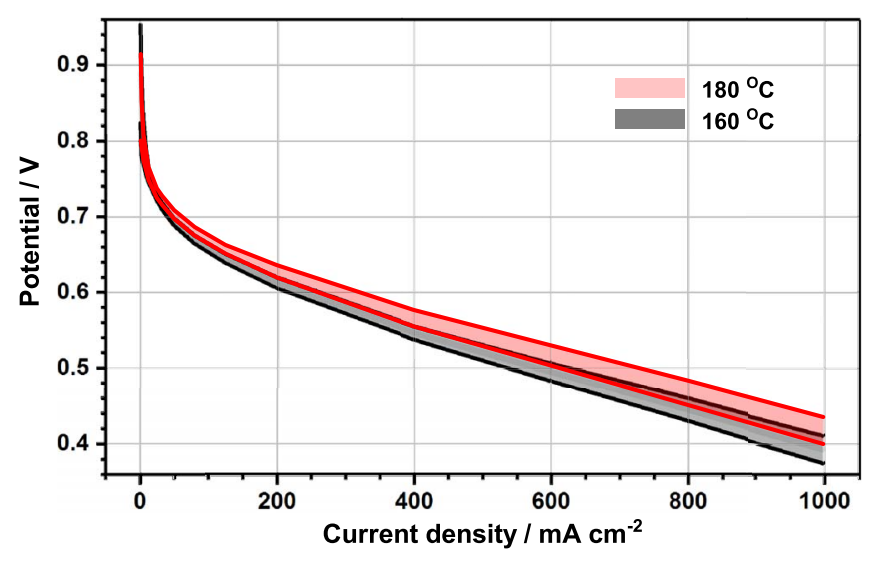

Figure 1. Mean BoL polarization curves for 8 cells operated at $160^{\circ} \mathrm{C}$ and for 8 cells operated at $180^{\circ} \mathrm{C}$, each with a width of two standard deviations.

technology is then not reflected by the results. Thus, from a lifetime benchmarking point of view, there is a risk that the results become obsolete shortly after they are acquired. As a result of the applied testing procedure, the investigation has been long underway, and this is reflected by the manufacturing date for the applied MEA batch, dating back to 2012. Obviously, the vast development of the technology that has taken place in the meantime is not evident from the results presented here. However, it is reasonable to presume that this does not influence the purpose of the study, which aims to elucidate fundamental degradation mechanisms and to evaluate the degradation that is taking place largely irrespective of the applied materials and manufacturing procedure.

The BoL performance in terms of standard deviation is displayed for all 16 MEAs in Figure 1. While all MEAs originated from the same manufacturing batch, 8 of the polarization curves were measured at $160^{\circ} \mathrm{C}$, whereas the other 8 were measured at $180^{\circ} \mathrm{C}$. In general, the BoL polarization curves show good reproducibility. In the low current density range, say up to $30-50 \mathrm{~mA} \mathrm{~cm}^{-2}$, there is little variation between samples. This suggests comparable performance for the electrodes since this region is dominated by activation polarization. At high current densities of up to $1000 \mathrm{~mA} \mathrm{~cm}^{-2}$, the polarization curves display a linearly decreasing performance, which is a sign of dominant contribution from ohmic resistance and, furthermore, suggests a lack of significant influence from concentration polarization (which, had it been present, is usually ascribed to mass transport limitations). However, as seen from the increasing width of the curves, there is some slight variation in the slopes, even for measurements carried out at the same temperature. The most obvious explanation for this is that the MEAs exhibit slight differences in area-specific series resistance (ASR) due to minor variations in ADL, membrane thickness, and/or contact resistance between layers of the cell. From regression analysis (elaborated in the following section), it was shown that the ASR at BoL was in the approximate ranges of $0.20-0.25 \Omega \mathrm{cm}^{2}$ and $0.17-0.24$ $\Omega \mathrm{cm}^{2}$ for the samples operated at 160 and $180^{\circ} \mathrm{C}$, respectively.

Area-specific resistance analysis._Lifetime data for a representative sample is shown in Figure 2; cf. the Supplementary Information for all other samples. This sample has been tested at $160^{\circ} \mathrm{C}, 600 \mathrm{~mA}$ $\mathrm{cm}^{-2}$, and with constant $\mathrm{H}_{2}$ /air flow rates of ca. 70/170 NmL min ${ }^{-1}$. Figure 2a shows selected polarization curves measured periodically over the $6000 \mathrm{~h}$ long lifetime test. Figure $2 \mathrm{~b}$ shows the change in steady-state voltage during the test. Figure $2 \mathrm{c}$ shows the ohmic contribution to the polarization curves along with the pertaining $i r$-free polarization curves, collectively corresponding to those in Figure 2a. These contributions have been partitioned using Equation 1. With no visual evidence of emerging limiting current behavior, this expression can be applied as a crude regression analysis of the polarization curves for quantitative estimation of the main factors that are contributing to the loss of potential. It should be emphasized that this simple fitting 

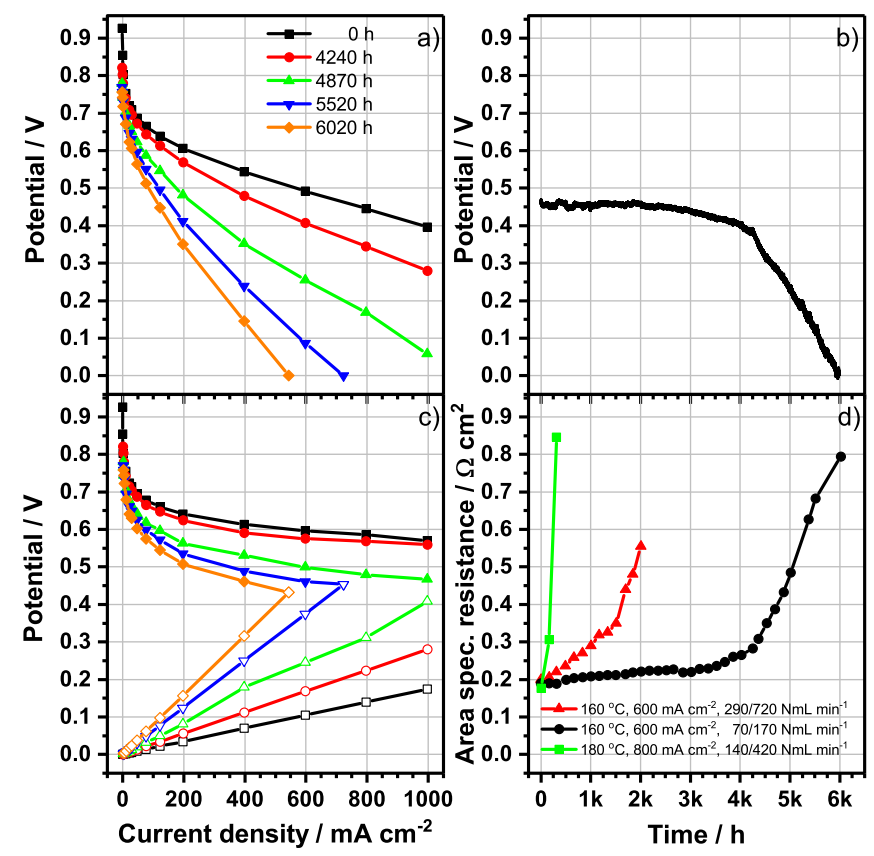

Figure 2. a) Polarization curves measured after the indicated amount of operating hours at steady-state conditions of $160^{\circ} \mathrm{C}, 600 \mathrm{~mA} \mathrm{~cm}^{-2}$, and with constant $\mathrm{H}_{2}$ /air flow rates of ca. 70/170 NmL min ${ }^{-1}$; b) Steady-state cell voltage as a function of operating hours; c) $i r$-loss curves and $i r$-free polarization curves obtained from a) via fitting to Equation 1; d) Variation of the series ASR as a function of operating hours with data included for two other cells as well.

procedure yields average values of the partitioned terms, whereas variation between individual points of the polarization curve is highly likely, e.g., due to change in the water balance when the current density is increased. In the equation, $E$ is the cell voltage, $a$ is a fitting parameter that resembles the OCV, $i$ is the current density, $r$ is the ohmic resistance of the system in terms of ASR, and $b$ is the Tafel slope.

$$
E=a-i r-b \log (i)
$$

The development of ASR for this sample is shown in Figure $2 \mathrm{~d}$ along with the development for two of the other samples, chosen to comparatively illustrate the trend. One of the additional samples has been operated at steady-state conditions of $160^{\circ} \mathrm{C}, 600 \mathrm{~mA} \mathrm{~cm}^{-2}$, and with constant $\mathrm{H}_{2}$ /air flow rates of ca. $290 / 720 \mathrm{NmL} \mathrm{min}^{-1}$. The other sample has been operated at steady-state conditions of $180^{\circ} \mathrm{C}, 800 \mathrm{~mA}$ $\mathrm{cm}^{-2}$, and with constant $\mathrm{H}_{2}$ /air flow rates of ca. $140 / 420 \mathrm{NmL} \mathrm{min}^{-1}$. As a general observation, increasing the gas-flow rate, temperature, and/or the current density will cause acceleration of the development in ASR. Moreover, even faster development is seen if more than one parameter is increased at a time. This is discussed in detail in the following sections.

As seen from the steady-state performance in Figure $2 b$, the cell voltage displays a steady decrease from 0.46 to $0.41 \mathrm{~V}$ over the first $4200 \mathrm{~h}$. This corresponds to a degradation rate of about $13 \mu \mathrm{V} \mathrm{h}^{-1}$. It is evident from Figure $2 \mathrm{c}$ that the ir-free polarization curves exhibit only a small change during this period of operation, suggesting marginal catalyst and electrode degradation up until then. Meanwhile, the ASR increases from 0.2 to $0.29 \Omega \mathrm{cm}^{2}$ during that same period; cf. Figure $2 \mathrm{~d}$. This clearly indicates that increasing ohmic resistance is a main contributing factor to the loss of performance during the first $4200 \mathrm{~h}$. Oftentimes, such development is ascribed to a decrease of the electrolyte conductivity, which is in fact also argued in the following sections on the grounds of acid loss. It serves to mention, however, that other factors unrelated to acid loss may participate to the development of ASR as well, e.g., poor interfacial contact between MEA- or cell components, poor electrical conductivity due to build-up of corrosion products, and poor ion conductivity due to electrolyte dehydration.

After $4200 \mathrm{~h}$ and until the end-of-test (EoT), the cell voltage decreases at a much faster rate of about $200 \mu \mathrm{V} \mathrm{h}^{-1}$. As seen in Figure $2 d$, this is partly due to the development in ASR, which increases more dramatically during this time. Acid loss might explain this if the dependence of ASR becomes increasingly prominent with the approach of a certain critical value of ADL. ${ }^{34,35}$ Eberhardt et al. ${ }^{23}$ also observed accelerated development of the ASR and ascribed it to aggravated contact resistance concomitant with the evaporation of acid volume from their cell, which was operated in a constant gap setup. While consequential thinning of the electrolyte membrane appears as a plausible explanation in their case, ${ }^{36}$ the cells in this study were spring loaded and should therefore be less sensitive to membrane contraction. Thus, the reason is more likely found in the acid-membrane system, possibly due to the justification above of the ASR becoming more dependent on ADL as the acid content decreases. Regardless of whether the cells are spring loaded or not, aggravated contact resistance due to electrolyte thinning cannot be dismissed as contributing to the development of the ASR. On this note, the observation of progressively decreasing OCV might suggest a steadily increasing rate of gas crossover, which in fact may be a consequence of electrolyte thinning.

It should be noted that after $4200 \mathrm{~h}$ and until EoT, the $i r$-free logarithmic components of the polarization curves are shifting as well; $\mathrm{cf}$. Figure $2 \mathrm{c}$. These curves are indicative of increasing activation overpotential and therefore suggest a reduction of the catalytic performance. The default explanation of this is usually a decrease of the electrochemically active catalytic surface area (ECSA) caused by significant increase of the cathode catalyst particle size. While increase of the catalyst particle size is probable, the impact of this mechanism is not expected to accelerate after long-term operation without a significant manipulation of the potential, i.e., dynamic operation or long-term operation at high potential. It seems unlikely that the shift of the $i r$-free logarithmic components of the polarization curves can be ascribed to the limited deviations from steady-state operation that these cells have experienced, i.e., the periodic polarization curve samplings. Instead, we might ascribe the observation to decreasing ECSA due to loss of three-phase-boundary regions as a consequential secondary effect of severe acid loss whereby parts of the electrodes are rendered depleted of ion conducting phase..$^{23,37,38}$ While acid loss from the catalyst layer will also result in increased resistance, there should be no linear dependence on current in this case, so the effect should contribute neither to the ir-curves of Figure 2c nor to the ASR dependence shown in Figure 2d. However, the separation of ohmic and non-ohmic contributions by Equation 1 is a quite crude technique, and influence from some apparently linear contributions from the catalyst layer cannot be dismissed entirely.

Effect of gas-flow rates. - The durability results shown in Figure 3 are for the three samples that have been operated at $160^{\circ} \mathrm{C}$, $200 \mathrm{~mA} \mathrm{~cm}^{-2}$, and with constant $\mathrm{H}_{2}$ /air flow rates of ca. 70/170, $140 / 420$, or $290 / 720 \mathrm{NmL} \mathrm{min}^{-1}$; cf. Table I for stoichiometry specifications. Additionally, data for another sample, which has previously been published by the author group, ${ }^{32}$ is shown for comparison. This additional MEA is of the same size as the others and has been operated at comparable steady-state conditions though with even lower constant $\mathrm{H}_{2}$ /air flow rates of ca. $25 / 115 \mathrm{NmL} \mathrm{min}^{-1}$, which corresponds to stoichiometries of 2.0/4.0. It should be emphasized that rather than polarization curve sampling, this additional MEA has been exposed to weekly diagnostics in the form of electrochemical impedance spectroscopy only, except for at BoL and EoT. Furthermore, this MEA stems from a different manufacturing batch that is of newer fabrication date and that has some slight differences to the materials specifications (ADL of 10.5 and with platinum loadings of 0.36 and 0.9 $\mathrm{mg} \mathrm{cm}{ }^{-2}$ for the anode and cathode, respectively). Specifications for all of the other MEAs investigated in this work can be found in the section titled Preparation of MEAs. 


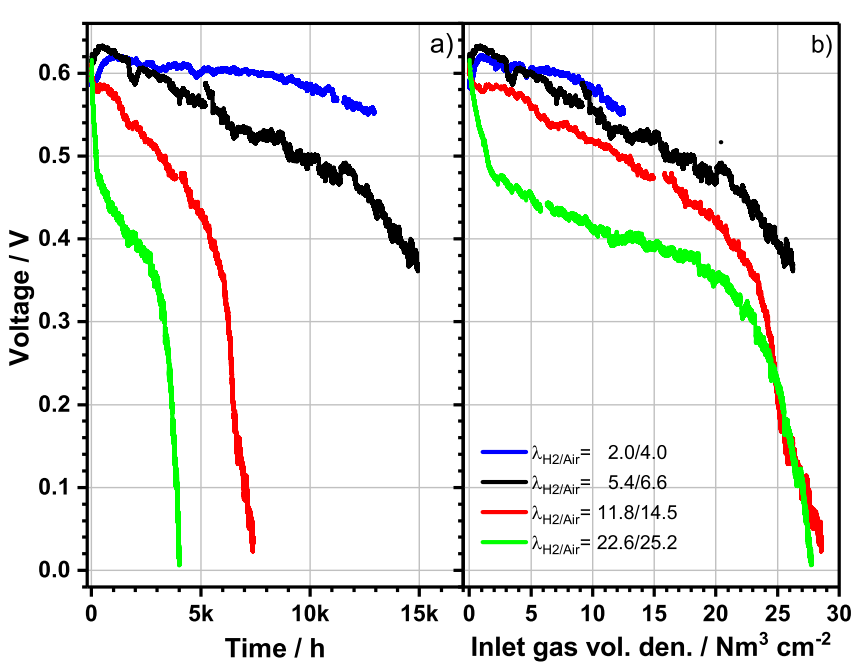

Figure 3. a) Steady-state lifetime curves for cells operated at $160^{\circ} \mathrm{C}, 200 \mathrm{~mA}$ $\mathrm{cm}^{-2}$, and with constant gas-flow rates corresponding to the stoichiometries indicated in the figure legend; b) The same data as in a) but presented as a function of the accumulated $\left(\mathrm{H}_{2}+\right.$ air $)$ gas-flow volume that has been supplied to the cell. As described in the text for this figure, the cell that has been operated with the lowest stoichiometries stems from a different manufacturing batch. ${ }^{32}$

It is clear from Figure $3 \mathrm{a}$ that the overall cell degradation rate increases as the gas-flow rates are increased from practical $\mathrm{H}_{2}$ /air stoichiometries of 2.0/4.0 to extremes of 22.6/25.2. This agrees with the conjecture that the primary mode of degradation is caused by acid loss via the evaporation mechanism. Assuming that the degradation is indeed affected primarily by this mechanism, an attempt was made at normalizing the degradation with respect to the accumulated volume of supplied $\left(\mathrm{H}_{2}+\right.$ air $)$ gas; cf. Figure $3 b$. Considering the nature of the evaporation mechanism and that the gas phase might become saturated with acid (or even oversaturated if carrying droplets or as an aerosol), it would probably be more correct to do the normalization with respect to the exhaust flow. On the other hand, it is the flow at inlet that is the readily controlled parameter. Furthermore, the actual change to the comparison one way or the other is quite small in this case even for the low stoichiometries. It is interesting to observe from Figure $3 \mathrm{~b}$ that the normalized degradation for these cells begin to accelerate after comparable amounts of $\left(\mathrm{H}_{2}+\right.$ air $)$ gas volumes have been supplied. As discussed in the previous section and further elaborated in the section titled Acid loss, this might suggest that a certain critical value of ADL is reached on account of progressive acid loss. It should be emphasized, that while the lifetime curves for the other samples do allude to a similar correlation, it is obvious only from the ones shown in Figure 3; cf. the Supplementary Information. The same can be said for the behavior during cell activation, which is discussed below. Presumably, this is because of increasing impact from other factors when operating at temperatures higher than $160^{\circ} \mathrm{C}$ and at current densities higher than $200 \mathrm{~mA} \mathrm{~cm}^{-2}$.

The cell activation process also seems affected by the gas-flow rate; cf. Figure 3a. At $\mathrm{H}_{2}$ /air stoichiometries of 2.0/4.0, peak performance is attained after about $1000 \mathrm{~h}$ of operation with a cell voltage increase of about $30 \mathrm{mV}$. For the higher $\mathrm{H}_{2} /$ air stoichiometries of 5.4/6.6, peak performance occurs after about $400 \mathrm{~h}$. With $\mathrm{H}_{2}$ /air stoichiometries of 11.8/14.5, no initial improvement of the cell voltage takes place. On the contrary, an immediate decrease was observed from $0.61 \mathrm{~V}$ at start-up to $0.58 \mathrm{~V}$ after approximately $150 \mathrm{~h}$. At even higher $\mathrm{H}_{2} /$ air stoichiometries of 22.6/25.2, the immediate decrease in performance becomes even more pronounced with the initial potential of $0.61 \mathrm{~V}$ decreasing to $0.46 \mathrm{~V}$ after only $300 \mathrm{~h}$. Following the cell activation or the initial loss of performance, the degradation rate is much steadier from then on for all of the cells.

It is worth noting that the MEAs used in this study were prepared at least 6 months before use and that they were kept in sealed plastic bags until tested. Thus, even after months of storage, these MEAs still exhibited activation behavior. This might suggest that an initial establishment of acid equilibrium at the membrane-catalyst interface entails involvement of an electrochemical mechanism, e.g., migration transfer of electrolyte ions. ${ }^{12}$ Other factors that potentially influence the behavior during cell activation include humidification of the membrane, removal of impurities from the catalyst surface, ripening of catalyst particles, and redistribution of the electrolyte in general. ${ }^{3}$ If a major effect is due to production of water, the activation will conceivably be affected by hygral expansion and decreased viscosity of the electrolyte, perhaps by easing transfer of acid to the catalyst layers where it may make for improved performance. ${ }^{2,4,39}$ It might be that the impact of gas-flow rates on the activation behavior is due to alteration of the water balance; high gas-flow rates might lead to more pronounced dehydration of the acid, which could hamper the allegedly beneficial transport of acid to the catalyst layers. In line with this, increased start-up temperature could also play a role since it too will affect the hydration of the acid..$^{15,40}$ As already mentioned, however, it has not been possible from these investigations to clearly visualize what effect the temperature has on the trend of the activation behavior; cf. the Supplementary Information.

An additional contribution to the cell activation is hypothesized; the activation behavior might be influenced by a liberation of catalytic sites concomitant with evaporation of excess acid in the electrodes, which is presumably causing some flooding at start-up. Such excessive amounts of acid might be transferred from the membrane in connection with MEA manufacturing, storage, and compression upon cell assembly. The effect of the latter is probably exacerbated during initial heating due to softening of the electrolyte with increase of temperature. In such a case, low flow rates should make for slow evaporation and for a slower activation of the electrode. Conversely, high flow rates should lead to much faster removal of the excess acid, though in conjunction with dehydration of the acid if the flow rates are inordinately high. What speaks against this hypothesis, is a lack of clearly visible limiting current behavior from the BoL polarization curves; cf. Figure 1. Such behavior should arise from excessive acid-flooding due to hampered supply of reactants. In light of this, the contribution of this mechanism to the activation behavior for these samples is most likely minor though it probably does carry some influence in conjunction with the other possible factors listed above.

Effect of current load and water production.-When examining the effect of current density, it is necessary to choose between employing either constant gas stoichiometries or constant gas-flow rates. The choice fell on constant gas-flow rates because, as shown in the preceding section, this parameter significantly affects the cell degradation rate. It should be noted, that for samples employing different current densities the exit flow rates are then not completely constant and neither is the humidity of the gasses; cf. Table I for humility estimations.

The effect that steady-state current density has on the cell durability is shown in Figure 4 for cells operated at $180^{\circ} \mathrm{C}$ and with constant $\mathrm{H}_{2}$ /air flow rates of ca. 70/170, 140/420, or 290/720 NmL $\mathrm{min}^{-1}$. Similar trends were observed for the cells operated at $160^{\circ} \mathrm{C}$; cf. the Supplementary Information. With constant $\mathrm{H}_{2}$ /air flow rates of ca. $70 / 170 \mathrm{NmL} \mathrm{min}^{-1}$, a steady-state current density of either 200 or $600 \mathrm{~mA} \mathrm{~cm}^{-2}$ was applied (insufficient flow for $800 \mathrm{~mA} \mathrm{~cm}^{-2}$ ); cf. Table I. For the two other sets of gas-flow rates, an additional measurement was carried out at $800 \mathrm{~mA} \mathrm{~cm}^{-2}$. The lifetime curves in Figure 4 clearly show that higher current density leads to faster overall degradation. This effect can be related to several factors including higher humidity, enhanced rate of charge transport, faster water production, and increased local temperature. As argued in the following, all of these secondary effects can justifiably increase the rate of acid loss, the latter of which is discussed in the following section titled Effect of temperature and dehydration.

As mentioned in the Introduction, water absorption by the hygroscopic phosphoric acid may encourage ionic conductivity via the vehicle mechanism in favor of structural diffusion via the Grotthuss 


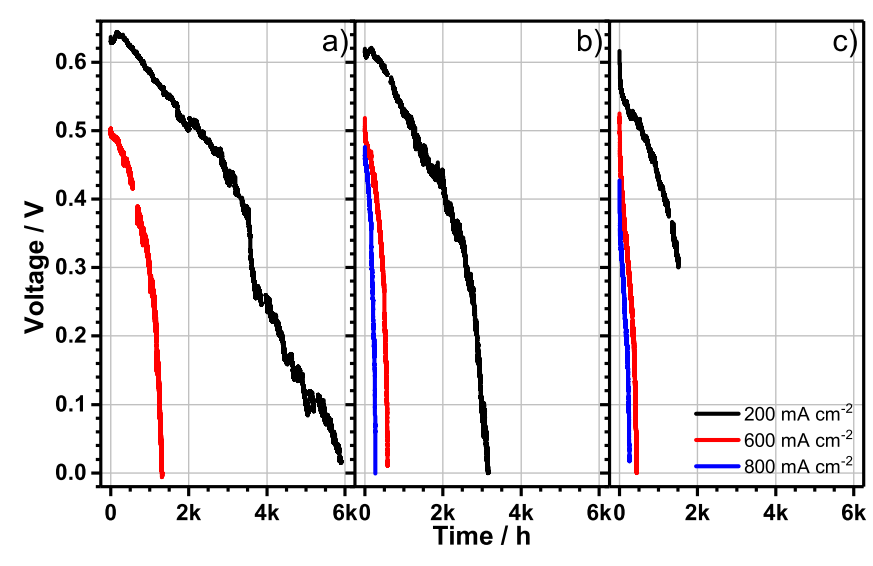

Figure 4. Lifetime curves obtained at $180^{\circ} \mathrm{C}$ with current densities of 200 , 600 , or $800 \mathrm{~mA} \mathrm{~cm}^{-2}$. The applied $\mathrm{H}_{2}$ /air flow rates were kept constant at approximately a) $70 / 170 \mathrm{NmL} \mathrm{min}^{-1}$, b) $140 / 420 \mathrm{NmL} \mathrm{min}^{-1}$, or c) $290 / 720$ NmL $\min ^{-1}$.

mechanism. ${ }^{12,13}$ Thus, it is possible that migration transfer of electrolyte ions is promoted at high current densities owing to the consequential increase of humidity. Any phosphate anions that migrate to the anode will recombine with the protons that are continuously formed there, leading to accumulation of phosphoric acid in this region. ${ }^{5,7,10,11}$ The accumulated acid is probably dispersed across large parts of the anode (and MPL/GDL).$^{5-7}$ This will presumably encourage its loss from the cell, e.g., via a combination of evaporation, surface diffusion, and possibly even dislodging of acid droplets. In a similar fashion, any hydronium cations that migrate to the cathode will be reduced upon reaching their destination, causing electroosmotic water drag and accumulation of water in that region. ${ }^{12,13}$ Quite probably, this will promote acid loss via the same mechanisms, perhaps with additional influence from decreased viscosity and from the proposed steam distillation mechanism. ${ }^{9}$ Obviously, migration transfer will become more prominent as the current density (rate of charge transport) increases because it is tantamount to transporting a larger amount of ions. ${ }^{11}$ This has previously been evidenced visually through $\mathrm{X}$-ray imaging by Eberhardt et al. ${ }^{5,7}$ who saw acid migration and loss to the flow field during dynamic use of an HT-PEMFC. In addition to migration, electrolyte transfer from the MEA might arise on account of decreased viscosity and hygral expansion of the electrolyte as the acid absorbs water, which is produced at high rates when the current density is high. ${ }^{28,39}$

The volatility of phosphoric acid will also vary with water content. ${ }^{16,17}$ Intuitively, adding water to concentrated phosphoric acid should dilute the acid and cause a lowering of its vapor pressure in accordance with Raoult's law. However, in this particular case, orthophosphoric acid tends to polymerize into di-, tri- and polymers through liberation of water at the temperature of operation. Furthermore, orthophosphoric acid, being the smallest of the phosphate species, is probably the most volatile. As water loss promotes polymerization, it serves to lower the concentration of the ortho-phosphoric acid and, thus, lowers its vapor pressure accordingly. Increased water production at higher current densities will reverse the condensation process, rendering the concentration of ortho-phosphoric acid higher, consequently increasing its vapor pressure. In effect, this may aggravate acid loss via evaporation. As already mentioned, faster water production might also instigate acid loss via the proposed steam distillation mechanism. ${ }^{9}$ In this regard, it serves to mention that while transport of water from the cell occurs primarily from the cathode side, some of it will permeate the membrane and leave with the anode exhaust. ${ }^{41}$

Effect of temperature and dehydration.-The effect that a change in temperature from 160 to $180^{\circ} \mathrm{C}$ has on the cell durability is shown in Figure 5 for cells operated at $600 \mathrm{~mA} \mathrm{~cm}^{-2}$ and with constant $\mathrm{H}_{2}$ /air flow rates of approximately $70 / 170,140 / 420$, or $290 / 720 \mathrm{NmL}$

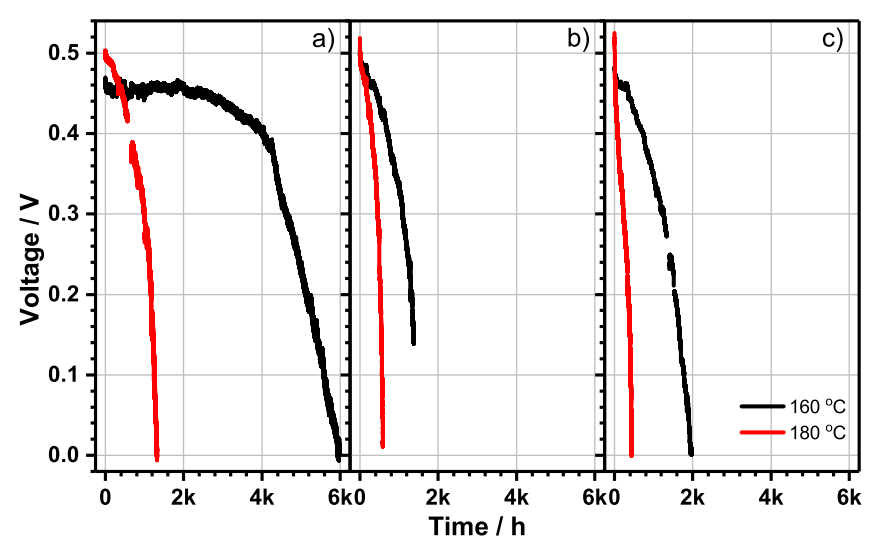

Figure 5. Lifetime curves obtained at $600 \mathrm{~mA} \mathrm{~cm}^{-2}$, a temperature of either 160 or $180^{\circ} \mathrm{C}$, and with constant $\mathrm{H}_{2}$ /air flow rates of aproximately a) $70 / 170$ $\mathrm{NmL} \min ^{-1}$, b) $140 / 420 \mathrm{NmL} \mathrm{min}{ }^{-1}$, or c) $290 / 720 \mathrm{NmL} \mathrm{min}^{-1}$.

$\min ^{-1}$. As a general trend, the cells degrade much faster at $180^{\circ} \mathrm{C}$ than at $160^{\circ} \mathrm{C}$, probably because the increased temperature encourages dehydration of the electrolyte as well as acid loss via evaporation. Crudely assuming that all of the product water remains in the cathode gas stream, the relative humility level of the air exhaust across all of the investigated samples varies between $0.2 \%\left(180^{\circ} \mathrm{C}, 200 \mathrm{~mA} \mathrm{~cm}^{-2}\right.$, and a supplied constant air flow rate of ca. $720 \mathrm{NmL} \mathrm{min}^{-1}$ ) and $4.8 \%$ $\left(160^{\circ} \mathrm{C}, 600 \mathrm{~mA} \mathrm{~cm}-2\right.$, and a supplied constant air flow rate of ca. $170 \mathrm{NmL} \min ^{-1}$ ); cf. Table I.

The disparate humidity between samples will most likely cause variation in the electrolyte water content. Since oxygen solubility and diffusivity in phosphoric acid are functions of the acid concentration, this might restrict the transport of oxygen to the catalytic sites when the acid in the catalyst layer becomes increasingly dehydrated; ${ }^{42}$ with phosphate ions having high affinity to the surface of platinum, it is often assumed that the active catalytic sites are covered by a film of acid. $^{43,44}$ Just like acid loss, dehydration might also make for increased ASR on account of reduced ionic conductivity, though via a combination of the following probable influential factors. ${ }^{12-15}$ First of all, dehydration increases the electrolyte viscosity. This will most likely restrict the viscous flow such that the ionic transport taking place via the vehicle mechanism becomes impeded. Most probably, this will also complicate reorientation of phosphoric acid molecules, which is required for conductivity via the Grotthuss mechanism. Secondly, the degree of structural diffusion via the Grotthuss mechanism might altogether become reduced at low humidity because formation of acid condensates reduces the number of proton donor groups contributing to this conductivity mechanism. Finally, with limited water content, the degree of acid deprotonation by water will be less pronounced. This may inhibit formation of the electrolyte ions that are contributing to the vehicle mechanism the most. Thus, the overall conductivity might become decreased compared to what is attainable at higher humidity.

During operation, heat is primarily produced in the membrane and in the electrodes. It is then conducted through the MPLs/GDLs to the flow channels where part of it is carried out by the gasses while the rest is conducted onwards through the flow plates. The driving force for the conduction of the heat must be a temperature gradient through the cell components; cf. the Supplementary Information for a schematic representation. Thus, the temperature is higher in the MEA than in the end plates or flow plates. With regard to degradation, especially if caused by acid evaporation, it is this in situ temperature of the MEA that is of particular interest-not that which is measured in the end plate, as is the common practice. The in situ temperature of the electrolyte was therefore measured to elucidate to what extent this parameter is affected by the current load. As seen from Figure 6, the temperature was recorded during the measurement of polarization curves at BoL, after $335 \mathrm{~h}$, and after $645 \mathrm{~h}$ of steady-state operation 


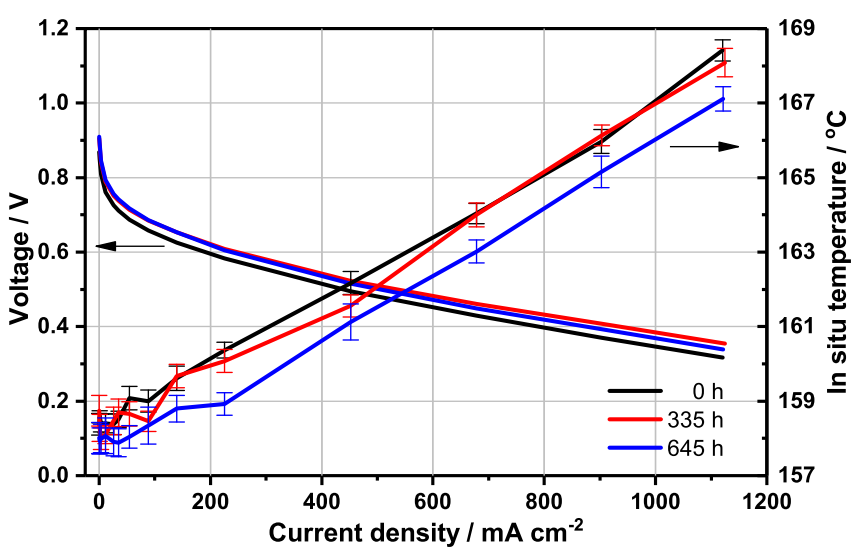

Figure 6. In situ temperature measurements of the membrane electrolyte during polarization curve samplings recorded at $\mathrm{BoL}$, after $335 \mathrm{~h}$, and after $645 \mathrm{~h}$ of steady-state operation with a current density of $200 \mathrm{~mA} \mathrm{~cm}{ }^{-2}$, constant $\mathrm{H}_{2} /$ air flow rates of ca. $50 / 310 \mathrm{NmL} \mathrm{min}^{-1}$, and a setpoint temperature of $160^{\circ} \mathrm{C}$ as measured in the end plate. As described in the pertaining text for this figure, this cell has been subjected to slightly different conditions than specified in the Experimental section.

with a setpoint temperature of $160^{\circ} \mathrm{C}$ (measured in the end plate close to the heating elements). The applied MEA in this case was marginally different from the other 16 samples in that the electrolyte had been made from two individual membranes, each with a dry-state thickness of $20 \mu \mathrm{m}$, sandwiched together with a micro-wire thermocouple in between; cf. the Experimental section titled In situ temperature measurements. Furthermore, the testing conditions were slightly different for this sample in that the polarization curves were measured up to ca. $1100 \mathrm{~mA} \mathrm{~cm}^{-2}$ and because $\mathrm{H}_{2} /$ air flow rates of ca. $50 / 310 \mathrm{NmL} \mathrm{min}^{-1}$ were applied during the steady-state operation at $200 \mathrm{~mA} \mathrm{~cm}^{-2}$.

It may be seen from Figure 6 that the local temperature increases by ca. $10^{\circ} \mathrm{C}$ as the current density is scanned from 0 to ca. $1100 \mathrm{~mA}$ $\mathrm{cm}^{-2}$. This effect can be explained mainly by the ohmic resistance, which causes heat production proportional to the current density. The ensuing temperature elevation might adversely affect the long-term durability on account of electrolyte dehydration as explained in this section already. In addition, the increased temperature will probably also encourage evaporation of the acid. ${ }^{16,17}$ It may be realized that the in situ temperature measurement at OCV differs from that of the setpoint temperature by ca. $1-2^{\circ} \mathrm{C}$. This offset can possibly be ascribed to the difference in measurement location (electrolyte vs. end plate), which should be hotter close to the heating elements when no current is being drawn from the cell. Alternatively, there may be some slight bias in the measurement signal for either of the thermocouples. As mentioned in the Experimental section, however, the micro-wire thermocouple had been thoroughly calibrated before use so the bias is probably insignificant in its case.

Acid loss.-As mentioned in the Introduction, the severity of acid loss might be underestimated as a mode of degradation when evaluated be means of off-gas analysis. To circumvent this issue, measurements were carried out using acid-base titration instead, thereby estimating the area-specific acid-loss rates for the 16 tested MEAs as average values from BoL and until EoT. These measurements are shown in Figure 7 with the rates of acid loss given as a function of current density and of the supplied $\left(\mathrm{H}_{2}+\right.$ air $)$ gas-flow rate at either $160^{\circ} \mathrm{C}$ (Figure $7 \mathrm{a}$ ) or $180^{\circ} \mathrm{C}$ (Figure $7 \mathrm{~b}$ ). As was also done for Figure 3, these results are shown relative to the gas-flow rate that was supplied to the cells-not the flow rate of the exhaust. This was deemed the most perspicuous representation since the effect of water production is then encompassed only by the current density.

Obviously, there is some scatter between the acid-loss measurements, particularly evident for the sample that has been operated at $160^{\circ} \mathrm{C}, 600 \mathrm{~mA} \mathrm{~cm}{ }^{-2}$, and with $\left(\mathrm{H}_{2}+\right.$ air $)$ gas-flow rate of ca. $560 \mathrm{NmL} \mathrm{min}^{-1}$. From visual assessment of the collective acid-loss data, this measurement stands out because the acid-loss rate is higher than expected. When comparing the lifetime curve for this sample to the one operated with higher gas-flow rates but otherwise similar conditions (Figure 5b vs. Figure 5c), the performance degradation also seems to proceed at a rate that is faster than expected. Thus, certain reservations might be in order regarding the data evaluation, particularly for this specific MEA. As a general trend, however, it is evident that the rate of acid loss increases with increasing magnitude of any of the applied stressor parameters. The strong correlation between acid loss and the stressors of both gas-flow rate $\left(\mathrm{H}_{2}+\right.$ air $)$ and temperature indicates a significant contribution from the acid evaporation mechanism. In addition, it is evident that the acid-loss rate depends also on the current density, even for samples that have been operated with approximately equal gas-flow rates. This observation is highly interesting because it directly contradicts the results by Eberhardt et al. $^{23}$ who concluded that the acid-loss rate, when normalized in
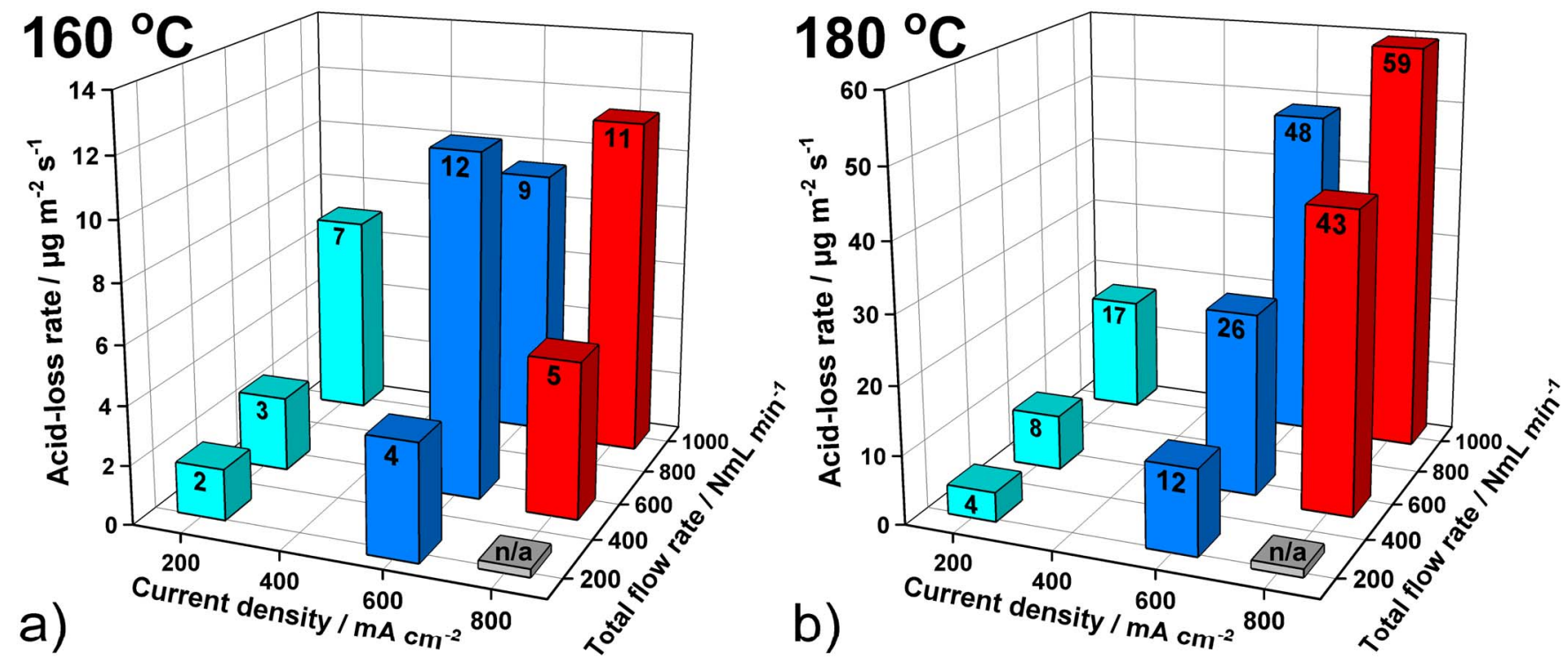

Figure 7. Average area-specific acid-loss rates during the time from $\mathrm{BoL}$ and until EoT as a function of steady-state current density and of supplied $\left(\mathrm{H}_{2}+\right.$ air $)$ gas-flow rate for operation at either a) $160^{\circ} \mathrm{C}$ or b) $180^{\circ} \mathrm{C}$. 
terms of gas-flow volume, was independent of the applied current density. As already mentioned, however, they have observed accumulation of acid at the anode in separate publications, and their results suggest that the effect is more pronounced with increasing current density and also that it is promoted by an increasing amount of free acid in the membrane. 5,7

The turning point of accelerated degradation rate (Figure 3), might correspond to a particular amount of acid loss and, thus, to a specific ADL of the membranes. Crudely assuming that the average rate of acid loss shown in Figure 7 is constant over the course of each individual test, an approximate ADL of 4.4-5.8 has been estimated at the turning point for the samples operated at $160^{\circ} \mathrm{C}, 200 \mathrm{~mA} \mathrm{~cm}{ }^{-2}$, and with constant $\mathrm{H}_{2}$ /air flow rates of ca. 70/170, 140/420, or 290/720 $\mathrm{NmL} \min ^{-1}$; cf. Figure 3. However, a significant caveat should be emphasized in that the acid-loss rate has been suggested to increase over the course of long-term operation, an observation that has been claimed based on loss estimations via off-gas analysis. ${ }^{28}$ On the other hand, this might be an artifact of acid re-condensation before reaching the location where the remainder is actually collected for analysis. ${ }^{8}$ If so, an increasing rate of acid loss might be explained by the impact of re-condensation dwindling during operation because the path downstream of the MEA approaches saturation with acid. Also based on off-gas analysis, the acid-loss rate has conversely been suggested as being lower after long-term operation compared to at BoL. ${ }^{20}$ This observation has been ascribed to a slowly established equilibrium in the MEA upon start-up in combination with evaporation of the acid that is probably in excess initially, say due to having been squeezed from the membrane during cell assembly and start-up. If the acid-loss rate does in fact decrease over time, the actual ADL at the point of accelerated degradation is probably lower than the estimated range. In summary, it is difficult to assess whether it is in fact the approach of the estimated ADL that is the cause for the observed acceleration in degradation rate. However, the estimated range of ADL does fall into (or close to) the range in which the conductivity is seemingly changing significantly with that of acid content. ${ }^{34,35}$ Notice in this regard that even though the applied acid determination technique measures the remaining acid in the MEA, some of it might not be located such that it can contribute to the performance or to the ADL of the membrane.

By extrapolating the equilibrium acid vapor pressure measurements by Brown and Whitt, ${ }^{16}$ Jakobsen et al. ${ }^{8}$ estimated the acid vapor pressure at temperatures low enough for practical fuel cell operation. Applying the extrapolated vapor pressure data as reference values for unity concerning acid saturation, it is then possible to normalize the measurements of acid loss from HT-PEMFCs in terms of degree of acid saturation. This has been done in Figure 8, which contains all of the data points given in Figure 7 along with selected literature values measured by off-gas analysis. ${ }^{9,18,23,29}$ Thus, Figure 8 shows the same compiled data on the $y$-axis but presented on three different $\mathrm{x}$-axes as a function of temperature (Figure 8a), area-normalized gas-flow rate (Figure $8 \mathrm{~b}$ ), and current density (Figure $8 \mathrm{c}$ ). The data are a mixture of anode-, cathode-, and collective measurements, for which the area-normalized flow rates in Figure $8 b$ correspond to either the anode/cathode side of the off-gas measurement itself or to the total of these values in the case of collective measurements (such as those in Figure 7).

An important observation for the acid-loss measurements compared in Figure 8 is that there is significant scattering between the results from different author groups. Of the references, it is only in the work by Eberhardt et al. ${ }^{23}$ that re-condensation of acid in the exhaust tubing is explicitly mentioned as having been accounted for. This may explain why their values are somewhat higher than that of the other references. It is clear that most of the acid-loss measurements carried out in this work do exceed those of the referenced literature values. This indicates that the severity of acid loss might be inadequately estimated when done exclusively by off-gas analysis. It serves to mention that this rationale contradicts a comparison carried out by Eberhardt et al., ${ }^{23}$ which showed good correlation between off-gas measurements of accumulated acid loss when compared to the acid

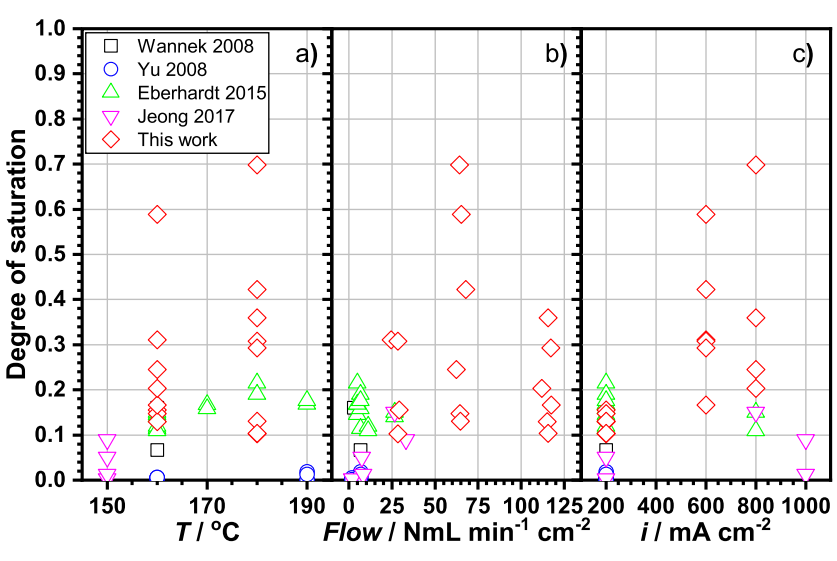

Figure 8. Acid-loss measurements from Figure 7 and from literature, 9,18,23,29 normalized in terms of degree of saturation (unity corresponding to the acid vapor pressure at lower temperatures extrapolated by Jakobsen et al. ${ }^{8}$ from the measurements of Brown and Whitt). ${ }^{16}$ The same sets of data are given as function of a) temperature, b) area-normalized flow rate, and c) current density.

that remained after testing (when including the acid that was in the part of the membrane clamped between sub-gaskets).

While determinations by off-gas analysis are less likely to ever exceed unity in this normalized comparison, evaluations by acid-base titration could presumably do so because they encompass all acidloss mechanisms-not just those for which loss occurs via the gas phase. On this note, droplets or aerosol, which may conceivably be carried with the gas phase, will probably not make it out of the cell before sticking to, say, the exhaust tubing, thereby being retained in the system. Even still, the acid-loss measurements in this work do not exceed what is theoretically possible following this comparison. Obviously, there is still a risk that the magnitudes of the acid-loss mechanisms might not be captured in their entirety regardless of the applied measurement technique. It would be highly interesting to partition by severity all of the different acid-loss mechanisms, i.e., out of the cell (the gas phase), re-condensed in the exhaust tubing, absorbed by the flow plates, absorbed by the GDLs, remaining in the membrane/catalyst layers, etc. However, this would require a much more detailed determination of the acid loss/redistribution than what has been carried out in this work.

It should be emphasized that the applied approach for normalization of the acid-loss data is an uncertain one. First of all, acid-loss measurements may be affected by differences in test conditions, say the applied cell materials or cell design. Though the applied test conditions are comparable for results in this work, disparities are frequently encountered when comparing results from different author groups-the flow field design being a common discord. Furthermore, the measurements by Brown and Whitt ${ }^{16}$ are inherently predisposed to uncertainty, particularly in the low temperature range $\left(>220^{\circ} \mathrm{C}\right)$ because they quantify very minute amounts of acid in the vapor phase. Additionally, the data at even lower temperature is prone to more uncertainty on account of the extrapolation itself. In this connection, it should be pointed out that Eberhardt et al. ${ }^{23}$ evaluated the condition of saturation from measurements of the exhaust acid content from a phosphoric acid fuel cell. Doing so, they claimed that their results, which are summarized in Figure 8, were actually at saturation (160$180^{\circ} \mathrm{C}$; there was some deviation at $\left.190^{\circ} \mathrm{C}\right) .{ }^{45}$ While it is obvious that their values are far from unity in Figure 8, it is difficult to argue whether it is more or less accurate to employ these values as saturation references in favor of using the extrapolated measurements ${ }^{8}$ by Brown and Whitt. ${ }^{16}$

\section{Summary}

The long-term durability of high-temperature polymer electrolyte membrane fuel cells (HT-PEMFCs) was studied in this work. This was done by investigating identically fabricated membrane electrode assemblies (MEAs) based on acid-doped polybenzimidazole 
membranes that had been prepared by solution casting via solvent evaporation. The behavior during cell activation seems to be affected by the gas-flow rate, and it was found that the MEAs exhibit activation behavior even after months of storage. This might indicate that high temperature and/or involvement of an electrochemical mechanism is essential for its initiation. It is hypothesized that the activation process is influenced by electrolyte evaporation from the electrodes, which probably contain excess amounts of acid following start-up. This effect may participate in establishing equilibrium upon startup alongside other effects such as water balance, acid redistribution, impurity removal, etc.

Employing stressors in the form of gas-flow rate, temperature, and current density, the rate of voltage decay at steady-state operation was increased with the magnitude of any of the applied stressors. This was correlated to the rate of acid loss. Some of the cells showed that after some steady loss of performance, an accelerated degradation rate set in at a point dictated to a large degree by the accumulated gas-flow volume. From time resolved polarization curves, the cause of this was identified as progressively aggravated activation overpotential in combination with accelerated development of area-specific series resistance (ASR). Both the steady degradation and the ensuing acceleration was ascribed to acid loss. Increasing ASR is indicative of this degradation mode since it depends highly on the ionic conductivity, which is provided by the phosphoric acid. Accelerated development of the ASR might be explained by its dependence on acid content becoming more prominent as a certain critical value of acid-doping level is approached. It is suggested that the aggravated activation overpotential is due in part to a secondary effect of severe acid loss, which eventually renders regions of the electrodes deprived of acid.

Since the rate of acid loss is affected by the temperature as well as by the $\left(\mathrm{H}_{2}+\right.$ air $)$ gas-flow rate, it seems that a major part of the increasing ASR is due to acid loss via evaporation, though dehydration of the electrolyte might also be an influencing factor of the increasing ASR. Concerning temperature, it is particularly the in-situ temperature that is of interest, and this was shown to increase by approximately $10^{\circ} \mathrm{C}$ when a current density of ca. $1100 \mathrm{~mA} \mathrm{~cm}^{-2}$ was drawn from the cell. However, the effect of current density is suggested to also involve consequential impact from higher humidity, increased charge transport, and faster water production. Higher humidity shifts the acid equilibrium towards formation of ortho-phosphoric acid species in favor of polymerized ones, thus, augmenting its vapor pressure and probably intensifying the overall acid evaporation as a result. Furthermore, higher humidity encourages water absorption by the phosphoric acid. This may give rise to acid loss on account of lower viscosity and hygral expansion of the electrolyte in combination with promoted ionic conductivity via the vehicle mechanism. With increased rate of charge transport, the vehicle mechanism dictates concomitant migration of electrolyte ions. In turn, this promotes accumulation of acid and water at the anode and cathode, respectively, and acid loss is probably encouraged by this. Actually, any liquid acid that accumulates at or is transported to or through the catalyst will conceivably be prone to dislodging, possibly forming acid droplets or aerosol. This is regardless of the mechanism by which it was transported there, e.g., squeezed by compression, hygral expansion, vehicle mechanism migration transfer, surface diffusion, capillary forces, or washing out with condensed water (the latter can probably be disregarded for these experiments). Finally, faster water production is expected to promote acid loss via a steam distillation mechanism.

\section{Conclusions}

Evaluating acid loss by off-gas analysis does not necessarily provide a realistic picture of the severity of this degradation mode. This is partly because the only mechanisms that are considered are those for which acid loss occurs via the gas phase but also because the acid in the gas phase can re-condense before it is collected. Acid-base titration should make for a more safeguarded characterization technique since it is the remaining acid in the MEA that is evaluated-not that, which is carried all the way out of the cell with the off-gasses. Depend- ing on the applied operating conditions, it is clear that acid loss can be highly significant, probably rendering many proposed operation modes and strategies detrimental for HT-PEMFCs. High temperature for improved performance, high current density during drive cycles, and high gas-flow rate for stack cooling will all make for potentially aggravated acid loss. Additionally, operation with reformate is expected to exacerbate the loss of acid compared to operation with pure hydrogen, partly because a higher gas-flow rate is required to reach the same stoichiometry but also because reformate often contains a high amount of water vapor. Thus, certain operation conditions might make for much more substantial acid loss than what has been suggested in literature up to now-even via the anode exhaust. In this connection, dead-end operation with hydrogen might be a more auspicious strategy, assuming that build-up of water is not as big of an issue as that of gas-flow rate. It is clear that any of the investigated parameters of temperature, gas-flow rates, or current density can be applied as accelerated stress test stressors with regard to the evaluation of acid loss. However, it is necessary to be mindful not only of how these parameters overtly affect the loss of acid but also of how they affect the humidity, which is a governing parameter for the acid loss as well. Considering the degradation mechanisms that are incited by water vs. the adverse effects of dehydration, there should be an optimum level of humidification where the long-term loss of electrolyte conductivity can be alleviated to some extent.

\section{Acknowledgments}

This work has been financially supported by the Danish ForskEL program (DuRaPEM III, no.2013-1-12064; UPCAT, no. 2015-112315; SmartMEA, no. 2014-1-12218) and by Innovation Fund Denmark (4M Centre, no. 12-132710).

\section{ORCID}

Lars Nilausen Cleemann (D) https://orcid.org/0000-0001-5840-7477

Hans Aage Hjuler (1D https://orcid.org/0000-0002-9846-0309

Jens Oluf Jensen (D) https://orcid.org/0000-0002-2427-7763

\section{References}

1. M. Molleo, T. J. Schmidt, and B. C. Benicewicz, in Fuel Cells: Selected Entries from the Encyclopedia of Sustainability Science and Technology, K.-D. Kreuer, Editor, p. 391, Springer, New York (2013).

2. K. Kwon, J. O. Park, D. Y. Yoo, and J. S. Yi, Electrochim. Acta, 54, 6570 (2009).

3. T. Tingelöf and J. K. Ihonen, Int. J. Hydrog. Energy, 34, 6452 (2009).

4. C. Wannek, I. Konradi, J. Mergel, and W. Lehnert, Int. J. Hydrog. Energy, 34, 9479 (2009).

5. S. H. Eberhardt, M. Toulec, F. Marone, M. Stampanoni, F. N. Büchi, and T. J. Schmidt, J. Electrochem. Soc., 162, F310 (2015)

6. S. Chevalier, M. Fazeli, F. Mack, S. Galbiati, I. Manke, A. Bazylak, and R. Zeis, Electrochim. Acta, 212, 187 (2016).

7. S. H. Eberhardt, F. Marone, M. Stampanoni, F. N. Büchi, and T. J. Schmidt, J. Elec trochem. Soc., 163, F842 (2016).

8. M. T. D. Jakobsen, J. O. Jensen, L. N. Cleemann, and Q. Li, in High Temperature Polymer Electrolyte Membrane Fuel Cells: Approaches, Status and Perspectives, Q. Li, D. Aili, H. A. Hjuler, and J. O. Jensen, Editors, p. 487, Springer (2016)

9. S. Yu, L. Xiao, and B. C. Benicewicz, Fuel Cells, 8, 165 (2008).

10. H. R. Kunz, in Tutorials in Electrochemical Engineering: Mathematical Modeling, R. F. Savinell, J. M. Fenton, A. C. West, S. L. Scanlon, and J. Weidner, Editors, Proceedings Volume 99-14, The Electrochemical Society Proceedings Series (1999).

11. H. Becker, L. N. Cleemann, D. Aili, J. O. Jensen, and Q. Li, Electrochem. Comm., 82, 21 (2017)

12. J.-P. Melchior, K.-D. Kreuer, and J. Maier, Phys. Chem. Chem. Phys., 19, 587 (2017).

13. J.-P. Melchior, G. Majer, and K.-D. Kreuer, Phys. Chem. Chem. Phys., 19, 601 (2017).

14. L. Vilčiauskas, M. E. Tuckerman, G. Bester, S. J. Paddison, and K.-D. Kreuer, Nature Chem., 4, 461 (2012).

15. C. Korte, F. Conti, J. Wackerl, and W. Lehnert, in High Temperature Polymer Electrolyte Membrane Fuel Cells: Approaches, Status and Perspectives, Q. Li, D. Aili, H. A. Hjuler, and J. O. Jensen, Editors, p. 169, Springer (2012).

16. E. H. Brown and C. D. Whitt, Ind. Eng. Chem., 44, 615 (1952).

17. S. Lang, T. J. Kazdal, F. Kühl, and M. J. Hampe, J Chem. Thermodyn., 68, 75 (2014).

18. C. Wannek, B. Kohnen, H.-F. Oetjen, H. Lippert, and J. Mergel, Fuel Cells, 8, 87 (2008).

19. Y. Oono, A. Sounai, and M. Hori, J. Power Sources, 189, 943 (2009).

20. T. J. Schmidt, in Polymer Electrolyte Fuel Cell Durability, F. N. Büchi, M. Inaba, and T. J. Schmidt, Editors, p. 199, Springer, New York (2009). 
21. C. Hartnig and T. J. Schmidt, Electrochim. Acta, 56, 4237 (2011).

22. F. J. Pinar, P. Cañizares, M. A. Rodrigo, D. Úbeda, and J. Lobato, J. Power Sources, 196, 4306 (2011).

23. S. H. Eberhardt, T. Lochner, F. N. Büchi, and T. J. Schmidt, J. Electrochem. Soc., 162, F1367 (2015).

24. Y. H. Jeong, J. H. Jung, E. Choi, S. Han, A. I. Begley, S. J. Yoo, J. H. Jang, H.-J. Kim, S. W. Nam, K.-Y. Lee, and J. Y. Kim, J. Power Sources, 299, 480 (2015).

25. N. Pilinski, M. Rastedt, and P. Wagner, Ecs Trans., 69, 323 (2015).

26. F. J. Pinar, M. Rastedt, N. Pilinski, and P. Wagner, Int. J. Hydrog. Energy, 41, 19463 (2016).

27. M. Rastedt, F. J. Pinar, N. Pilinski, A. Dyck, and P. Wagner, Ecs Trans. 75, 455 (2016).

28. D. Schonvogel, M. Rastedt, P. Wagner, M. Wark, and A. Dyck, Fuel Cells, 16, 480 (2016).

29. Y. H. Jeong, K. Oh, S. Ahn, N. Y. Kim, A. Byeon, H.-Y. Park, S. Y. Lee, H. S. Park, S. J. Yoo, J. H. Jang, H.-J. Kim, H. Ju, and J. Y. Kim, J. Power Sources, 363, 365 (2017).

30. M. Rastedt, V. Tullius, J. Büsselmann, D. Schonvogel, P. Wagner, and A. Dyck, ECS Trans., 80, 3 (2017).

31. United States Department of Energy (DOE), Office of Energy Efficiency and Renewable Energy, Fuel Cell Technologies Office, in: Multi-Year Research, Development, and Demonstration Plan, Fuel Cells chapter 3.4, (2016) https:// energy.gov/eere/fuelcells/downloads/fuel-cell-technologies-office-multi-yearresearch-development-and-22 (Accessed 9 November 2017).
32. T. Søndergaard, L. N. Cleemann, H. Becker, D. Aili, T. Steenberg, H. A. Hjuler, L. Seerup, Q. Li, and J. O. Jensen, J. Power Sources, 342, 570 (2017).

33. Omega https://www.omega.com/temperature/pdf/EXTT_EX_WIRE.pdf (Accessed 9 November 2017)

34. Y.-L. Ma, J. S. Wainright, M. H. Litt, and R. F. Savinell, J. Electrochem. Soc., 151, A8 (2004).

35. K. A. Perry, K. L. More, E. A. Payzant, R. A. Meisner, B. G. Sumpter, and B. C. Benicewicz, J. Polym. Sci. B-polym. Phys., 52, 26 (2014).

36. Y. Oono, A. Sounai, and M. Hori, J. Power Sources, 241, 87 (2013).

37. Y. Oono, A. Sounai, and M. Hori, J. Power Sources, 210, 366 (2012).

38. A. Suzuki, M. Williams, Y. Oono, R. Miura, N. Hatakeyama, M. Hori, and A. Miyamotoa, Ecs Trans., 61, 7 (2014).

39. W. Maier, T. Arlt, K. Wippermann, C. Wannek, I. Manke, W. Lehnert, and D. Stolten, J. Electrochem. Soc., 159, F398 (2012).

40. J. Lobato, P. Cañizares, M. A. Rodrigo, and J. J. Linares, Electrochim. Acta, 52, 3910 (2007).

41. U. Reimer, J. Ehlert, H. Janßen, and W. Lehnert, Int. J. Hydrog. Energy, 41, 1837 (2016).

42. K. Klinedinst, J. A. S. Bett, J. Macdonald, and P. Stonehart, J. Electroanal. Chem. Interfacial Electrochem., 57, 281 (1974).

43. Q. Li, G. Xiao, H. A. Hjuler, R. W. Berg, and N. J. Bjerrum, J. Electrochem. Soc. 141, 3114 (1994).

44. R. Zeis, Beilstein J. Nanotechnol. 6, 68 (2015).

45. A. Seya and T. Harada, Fuji Electr. Rev., 47, 11 (2001). 